\title{
Studi ANAlisa Atap RangKa BaJA Model Paralel DAN SEGITIGA BERDASARKAN SNI 03-1729-2002
}

\author{
Safrin Zuraidah ${ }^{1)}$, Budi Hastono ${ }^{2)}$, Yasir Arofat ${ }^{3}$. \\ ${ }^{1)}$ Program Studi Teknik Sipil, Fakultas Teknik Universitas Dr. Soetomo Surabaya \\ J1 Semolowaru No.84, 60118 \\ Email : safrin.zuraidah@unitomo.ac.id \\ ${ }^{2)}$ Program Studi Teknik Sipil, Fakultas Teknik Universitas Dr. Soetomo Surabaya \\ Email : budi.hastono@unitomo.ac.id \\ ${ }^{3)}$ Program Studi Teknik Sipil, Fakultas Teknik Universitas Dr. Soetomo Surabaya \\ Email : yasirarofat05@gmail.com
}

\begin{abstract}
Steel trust roof for industrial buildings has a variety of models, including Gable frame model, Parallel, Polenciou, Triangle, and others. Each model has different strengths in accepting loads that work on building structures. The purpose of this study was to compare steel frame horses Parallel Model and Steel Triangle using a double-angled foot profile based on SNI 031729-2002 which resulted in a robust and efficient design with a stretch of $20 \mathrm{~m}$ and $30 \mathrm{~m}$. From the analysis, it is found that the steel roof structure uses the most efficient foot double foot profile on the span of $20 \mathrm{~m}$ and $30 \mathrm{~m}$ that is parallel model compared to the triangle model of the total weight percentage of $3.66 \% .8 .57 \%$ of the total weight of the triangle model.
\end{abstract}

Keywords : profile, design, efficient, parallel, triangle

\begin{abstract}
Abstrak
Atap rangka baja untuk bangunan industri mempunyai berbagai macam model, diantaranya model batang Tunggal Parallel, Polenciou, Segitiga, dan lai-lain . Masing-masing model mempunyai kekuatan yang berbeda-beda dalam menerima beban yang bekerja pada struktur bangunan. Tujuan dari penelitian ini untuk membandingkan atap rangka baja Model Paralel dan Segitiga baja mengunakan profil double siku sama kaki berdasarkan SNI 03-1729-2002 yang menghasilkan desain yang kuat dan efisien dengan lebar bentangan $20 \mathrm{~m}$ dan $30 \mathrm{~m}$. Dari hasil analisa yang didapatkan, bahwa struktur atap baja mengunakan profil double siku sama kaki yang paling efisien pada bentangan $20 \mathrm{~m}$ dan $30 \mathrm{~m}$ yaitu model paralel dibandingkan model segitiga dari prosentase berat total masing-masing sebesar 3,66\%. 8,57\% dari berat total model segitiga.
\end{abstract}

Kata kunci : profil, desain, efisien, paralel, segitiga

\section{Pendahuluan}

Pergudangan mempunyai peranan sangat penting untuk penyimpanan produk sebelum melaksanakan distribusi ke pasar, oleh karena itu dibutuhkan kontruksi bangunan yang dapat mengakomodasi keperluan dengan aman, ekonomis dan kuat. Sehingga memicu berbagai solusi untuk menyelesaikan permasalahan pembangunan gudang pabrik dengan cara memodifikasi kontruksi yang berupa perbandingan model kontruksi yang lebih kuat, ringan dan murah guna mendapatkan bangunan yang nyaman dan aman sesuai perundangan kontruksi tentang standarisasi.

Kontruksi baja menjadi pilihan yang tepat pada pembangunan gudang pabrik, sebab kontruksi baja dengan bentangan panjang lebih efisien untuk bentang panjang, serta banyak tersedia di pasaran macam tipe material baja ) .

Kontruksi baja ialah sebuah struktur rangka baja yang terdiri dari susunan beberapa batang-batang baja yang disambung menjadi kumpulan-kumpulan bentuk segitiga yang banyak pada atap bangunan. Atap sendiri merupakan bagian dari bangunan yang letaknya berada dibagian paling atas, bisa di katakan jika konstruksi baja ini merupakan rangka di bagian atap sebuah bangunan besar seperti bangunan pabrik, gudang pabrik. Untuk itu penelitian ini, melakukan studi analisa kuda-kuda rangka baja dengan perbandingan model paralel dan segitiga ditinjau dari segi kekuatan dan efisien, sesuai SNI 031729-2002

Tujuan penelitian ini adalah:

1. Untuk mengetahui stabilitas dan kekuatan dari dua model kuda-kuda rangka baja dengan bentangan yang berbeda.

2. Untuk menetukan desain kontruksi kuda-kuda rangka baja yang paling kuat dan efisien dari 2 model yang sudah dianalisa

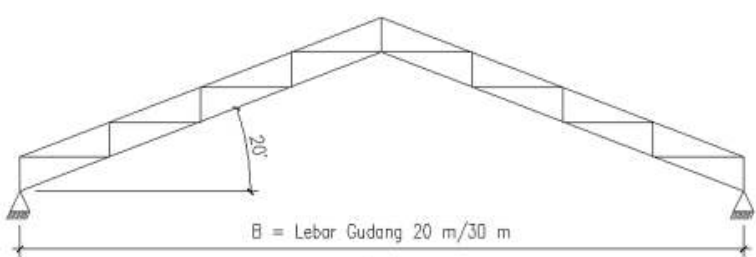

(a)

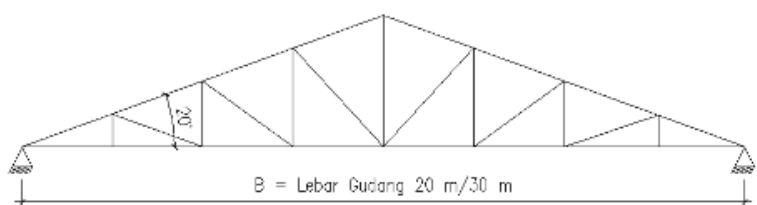

(b)

Gambar 1 Kuda-kuda rangka baja model paralel (a) dan model segitiga (b) 


\section{TINJAUAN PUSTAKa}

Struktur atap yaitu bagian bangunan yang menahan atau mengalirkan beban-beban dari atap. Struktur atap terbagi menjadi rangka atap dan penopang rangka atap.

Rangka atap berfungsi menahan beban dari bahan penutup atap sehingga umumnya berupa susunan balokbalok dari kayu, bambu, baja secara vertikal dan horizontal, kecuali pada struktur atap dak beton, berdasarkan posisi inilah maka muncul istilah gording, kasau dan reng. Susunan rangka atap dapat menghasilkan lekukan pada atap jurai dalam atau jurai luar dan menciptakan bentuk atap tertentu.

\section{Penelitian Sebelumnya}

Azhari dkk, 2015. Menyatakan analisa perencanaan kuda-kuda jenis rangka Howe dan rangka Pratt dengan bentangan $9 \mathrm{~m}$ kemiringan kuda-kuda $35^{\circ}$, tanpa meninjau sambungan, pelat buhul dan pelat kopel rangaka jenis Howe lebih ringan 20,7\% dari pada rangka Pratt.

Istiqomah, Ade Tias, 2015. Dari penelitian ini dapat disimpulkan bahwa penggunaan kuda-kuda model polenciau dengan bentangan kuda-kuda $27 \mathrm{~m}$ kemiringan atap $25^{\circ}$ dan menggunakan baja profil doubel siku sama kaki 80.80.14, 75.75.10 serta 50.50.5 kontrol dimensi pada rangka batang tidak melebih ijin perundangan kontruksi yang digunakan.

Jibja, Billah Wirat, 2016. Menyatakan hasil penelitian penggunaan kuda-kuda jenis rangka lengkung dengan bentangan $54 \mathrm{~m}$ dan kemiringan atap $8^{\circ}$, tanpa meninjau sambungan, pelat buhul dan pelat kopel sistem rangka batang lebih hemat berat strukturnya 13,89\% dibandingkan WF honeycomb dan 47,21\% dibandingkan WF biasa.

\section{Sifat-sifat Mekanis Baja}

Sifat-sifat mekanis baja dijelaskan dalam peraturan perundangan kontruksi Indonesia (SNI-03-1729-2002), untuk sifat-sifat mekanis dari material baja dapat dilihat tabel dibawah ini:

Tabel . 1 Sifat Mekanis Baja

\begin{tabular}{|ll|}
\hline Modulus Elastisitas, $E$ & $200.000 \mathrm{MPa}$ \\
\hline Modulus Geser, $G$ & $80.000 \mathrm{MPa}$ \\
\hline Angka poisson, $\mu$ & 0.30 \\
\hline Koefisien muai panjang, $\alpha$ & $12.10-6 /{ }^{\circ} \mathrm{C}$ \\
\hline
\end{tabular}

Modulus geser $(\mathrm{G})$ setiap bahan elastis dirumuskan sebagai besikut:

$$
\mathrm{G}=\frac{\mathrm{E}}{2(1+\mu)}
$$

Sedangkan untuk tegangan leleh dan tegangan putus tidak boleh diambil melebih nilai-nilai yang sudah ditetapkan pada SNI 03-1729-2002, tabel 5.3, yaitu:
Tabel 2 Tegangan Leleh dan Tegangan Putus

\begin{tabular}{|c|c|c|c|}
\hline \multirow{2}{*}{$\begin{array}{c}\text { Macam } \\
\text { Baja }\end{array}$} & $\begin{array}{c}\text { Tegangan } \\
\text { Putus } \\
\text { Minimum }\end{array}$ & $\begin{array}{c}\text { Tegangan } \\
\text { Leleh } \\
\text { Minimum }\end{array}$ & $\begin{array}{c}\text { Regangan } \\
\text { Minimum }\end{array}$ \\
\cline { 2 - 4 } & $f_{u}(\mathrm{MPa})$ & $f_{y}(\mathrm{MPa})$ & $\%$ \\
\hline & & 210 & 22 \\
BJ 34 & 340 & 240 & 20 \\
BJ 37 & 370 & 250 & 18 \\
BJ 41 & 410 & 290 & 16 \\
BJ 50 & 500 & 410 & 13 \\
BJ 55 & 550 & & \\
(Sumber, SNI-03-17-2002, tabel 5.3) \\
MPa = Mega pascal (sistem internasional) $=10 \mathrm{~kg} / \mathrm{cm}^{2}$
\end{tabular}

\section{Desain LRFD Struktur Baja}

Secara umum, suatu struktur dikatakan aman apabila memenuhi persyaratan sebagai berikut:

Dimana:

$$
\varnothing \mathrm{R}_{\mathrm{n}}=\sum \gamma_{\mathrm{i}}-\mathrm{Q}_{\mathrm{i}}
$$

$\varnothing \mathrm{R}_{\mathrm{n}} \quad=$ Tahanan rencana

$\sum \gamma_{\mathrm{i}}-\mathrm{Q}_{\mathrm{i}}=$ Jumlah beban terfactor

$\emptyset \quad=$ Faktor tahanan

$\mathrm{R}_{\mathrm{n}} \quad=$ Tahanan nominal

$\gamma_{\mathrm{i}}=$ Faktor beban

$\mathrm{Q}_{\mathrm{i}} \quad=$ Beban mati, beban hidup, angin dan gempa

\section{Kombinasi Pembebanan}

Kombinasi pembebanan yaitu tahanan rencana lebih besar dari total beban-beban kerja dikalikan dengan suatu faktor beban. Untuk kombinasi pembebanan ditentukan SNI 03-1729-2002, pasal 6.2.2, sebagai berikut:

1. $1,4 \mathrm{D}$

2. $1,2 \mathrm{D}+1,6 \mathrm{~L}+0,5(\mathrm{La}$ atau $\mathrm{H})$

3. 1,2 $\mathrm{D}+1,6(\mathrm{La}$ atau $\mathrm{H})+\left(\gamma_{\mathrm{L}} \mathrm{L}\right.$ atau 0,8 W) ...(3c)

4. 1,2 D + 1,3 W $+\gamma_{\mathrm{L}} \mathrm{L}+0,5(\mathrm{La}$ atau $\mathrm{H}) \ldots$ (3-d)

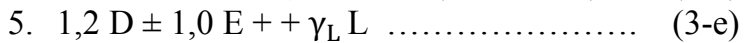

6. $0,9 \mathrm{D} \pm(1,3 \mathrm{~W}$ atau $1,0 \mathrm{E})$

\section{Struktur Tarik}

Komponen struktur yang memikul gaya tarik aksial terfaktor $\mathrm{N}_{\mathrm{u}}$, harus memenuhi:

$$
\mathrm{N}_{\mathrm{u}} \leq \emptyset \quad \mathrm{N}_{\mathrm{n}} \quad \ldots \ldots .
$$

Dengan $\varnothing N_{n}$ yaitu kuat tarik rencana yang besarnya diambil sebagian nilai terendah diantara dua perhitungan menggunakan harga-harga $\emptyset$ dan $N_{n}$ sebagai berikut:

Kontrol leleh (tengah batang)

$$
\begin{aligned}
& \varnothing=0,9 \\
& \mathrm{~N}_{\mathrm{n}}=\mathrm{A}_{\mathrm{g}} \mathrm{f}_{\mathrm{y}}
\end{aligned}
$$

Kontrol patah (daerah sambungan)

$$
\begin{aligned}
& \varnothing=0,75 \\
& N_{n}=A_{e} f_{u}
\end{aligned}
$$


Batas kelangsingan mengalami gaya tarik pasal 7.6.4 SNI 03-1729-2002 sebagai berikut:

$\lambda_{\max }=240$ (struktur utama)

$\lambda_{\max }=300$ (struktur sekunder)

Angka kelangsingan $\rightarrow \lambda=\frac{\mathrm{L}}{\mathrm{r}}$

\section{Struktur Tekan}

Suatu komponen struktur mengalami gaya tekan konsentrasi, akibat beban terfaktor $\mathrm{Nu}$, berdasarkan SNI 03-1729-2002, pasal 9.1 harus memenuhi.

$$
\mathrm{N}_{\mathrm{u}}<\varnothing_{\mathrm{c}} . \mathrm{N}_{\mathrm{n}}
$$

$\mathrm{N}_{\mathrm{n}}$ = Kuat tekan nominal komponen struktur yang

ditentukan sebagai berikut:

Dimana penampang mempunyai perbandingan lebar terhadap tebalnya lebih kecil dari pada $\lambda_{\mathrm{r}}$ (SNI 03-17292002, tabel 7.5-1) daya dukung nominal komponen struktur tekan dihitung sebagai berikut:

$$
\begin{aligned}
& \mathrm{Nn}=\operatorname{Ag} . \mathrm{fcr}=\operatorname{Ag} \frac{\mathrm{fy}}{\omega} \\
& \frac{\mathrm{fcr}}{\mathrm{fy}}=\frac{\pi^{2} \mathrm{E}}{\lambda^{2} \mathrm{fy}}=\operatorname{Ag} \frac{\text { fy }}{\omega} \\
& \text { Sehingga: } \rightarrow \lambda \mathrm{c}=\frac{\lambda}{\pi} \sqrt{\frac{\text { fy }}{\mathrm{E}}}
\end{aligned}
$$

Dimana:

Besaran $\omega$ ditentukan oleh $\lambda \mathrm{c}$, yaitu:

$$
\begin{array}{ll}
\lambda c<0,25 & \text { Maka, } \omega=1 \\
0,25<\lambda c<1,2 & \text { Maka, } \omega \frac{1,43}{1,6-0,67 \lambda c} \\
\lambda c>1,2 & \text { Maka, } \omega=1,25 \lambda c^{2}
\end{array}
$$

\section{Faktor Tekuk}

Harga $\omega$ dapat ditentukan dengan persamaan:

$\lambda g=\pi \sqrt{\frac{E}{0,7 \cdot \sigma \cdot l}}$

$\lambda s=\frac{\lambda}{\lambda g}$

\section{Dimana:}

$\lambda=$ Angka kelangsingan batang

$\mathrm{s}=$ Jarak antara sumbu-kesumbu dari baut yang berurutan

Untuk: $\quad \lambda s \leq 0,183 \rightarrow$ maka $\omega=1$

$$
\begin{aligned}
& 0,183<\lambda \mathrm{s}<1 \text { maka } \omega \\
& \lambda \mathrm{s} \geq 1 \rightarrow \text { maka } \omega=2,381 \lambda \mathrm{s}^{2}
\end{aligned}
$$

Kelangsingan batang struktur tekan

Kelangsingan pada batang struktur tekan dapat dicari dengan persamaan:

$$
\lambda \mathrm{s}=\frac{\mathrm{Lk}}{\mathrm{i}} \leq 200
$$

Dimana:

$\mathrm{Lk}=$ Panjang tekuk batang

$\mathrm{i}=$ Jari-jari kelembaman batang

Kelangsingan elemen penampang $<\lambda_{\mathrm{r}}$ Dimana: $\lambda_{\mathrm{r}}=\frac{250}{\sqrt{\mathrm{f}_{\mathrm{y}}}}($ SNI 03-1729-2002, tabel 7.5-1) untuk

elemen profil siku.

Kelangsingan pada arah tegak lurus sumbu $x-x$ (SNI 03-1729-2002, hal 29) dihitung dengan persamaan (2.40):

$$
\lambda \mathrm{x}=\frac{\mathrm{Lkx}}{\mathrm{ix}} \leq 200
$$

Dimana:

Lkx = Panjang tekuk komponen tersusun pada arah tegak lurus sumbu $\mathrm{x}-\mathrm{x}$, dengan memeperhatikan pengekang lateral yang ada, dan kondisi ujung-ujung komponen struktur (mm)

ix $=$ Jari-jari girasi komponen struktur pada arah sumbu $\mathrm{X}-\mathrm{X}$

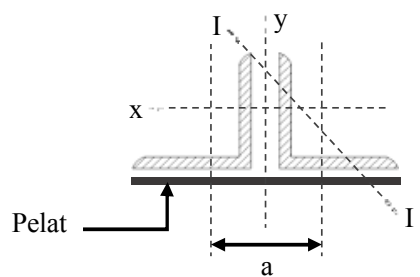

Gambar 2. Potongan profil doubel siku

Pada arah tegak lurus sumbu $y-y$, harus dihutung kelangsingan ideal $\lambda i y$ dengan persamaan:

$$
\begin{aligned}
& \lambda \mathrm{ix}={\sqrt{\lambda_{\mathrm{y}}}}^{2}+\frac{\mathrm{m}}{2} \lambda \mathrm{I}^{2} \\
& \lambda \mathrm{y}=\frac{\mathrm{Lky}}{\mathrm{ry}} \leq 200 \\
& \lambda \mathrm{I}=\frac{\mathrm{LI}}{\mathrm{r}_{\text {min }}} \leq 50
\end{aligned}
$$

Dimana:

$\mathrm{m}=$ Jumlah profil

Lky = Panjang tekuk komponen struktur pada arah tegak lurus sumbu $y-y$, dengan memperhatikan pengekang lateral dan kondisi jepit ujung-ujung komponen struktur ( $\mathrm{mm}$ )

ry $\quad=$ Jari-jari girasi komponen struktur pada arah komponen struktur tekan ( $\mathrm{mm}$ )

LI = Spasi antara pelat kopel pada arah komponen struktur tekan (mm)

$r_{\min }=$ Jari-jari girasi komponen struktur terhadap sumbu yang memberikan nilai terkecil

\section{Sambungan baut}

Jarak Baut dan Diameter Lubang Baut Jarak baut antara sumbu pusat lubang baut dan antara sumbu baut ujung bagian yang disambung, menurut SNI 03-1729-2002, pasal 13.4 diantaranya:

- Jarak sumbu lubang baut pusat

$$
3 \mathrm{~d}_{\text {lubang }} \leq \mathrm{S} \leq 15_{\text {tb }} \text { atau } 200 \mathrm{~mm}
$$

- Jarak sumbu lubang baut ujung atau tepi 
$1,5 \mathrm{~d}_{\text {lubang }} \leq \mathrm{U}_{1} \leq\left(4_{\mathrm{tb}}+100 \mathrm{~mm}\right)$

atau $200 \mathrm{~m}$

$\mathrm{U}_{2} \leq\left(12_{\mathrm{tb}}+150 \mathrm{~mm}\right)$

\section{Dimana:}

$\mathrm{d}_{\text {lubang }}=$ Diameter lubang $(\mathrm{mm})$

$t_{b}=$ Tebal plat yang disambung $(\mathrm{mm})$

- Diameter lubang baut, menurut SNI 03-17292002, pasal 17.3.6 yaitu:

a. Diameter baut $\leq 24 \mathrm{~mm}$, maka diameter lubang $+2 \mathrm{~mm}$

b. Diameter baut $\geq 24 \mathrm{~mm}$, maka diameter lubang $+3 \mathrm{~mm}$

Kuat Baut Memikul Beban

Syarat umum yang harus dipenuhi dalam merencanakan baut, menurut SNI 03-1729-2002, pasal 13.2.2 yaitu:

$\mathrm{R}_{\mathrm{u}} \leq \emptyset \mathrm{R}_{\mathrm{n}}$

Kuat geser nominal baut $\left(\mathrm{V}_{\mathrm{n}}\right)$

$\mathrm{V}_{\mathrm{n}}=\mathrm{r}_{1} \mathrm{f}_{\mathrm{u}}^{\mathrm{b}} \mathrm{A}_{\mathrm{b}} \mathrm{m}$

Dimana:

$r_{1}=0,50$ tanpa ulir pada bidang geser baut

$r_{1}=0,40$ ada ulir pada bidang geser baut

$\mathrm{f}_{\mathrm{u}}^{\mathrm{b}}=$ Tegangan tarik putus baut

$\mathrm{A}_{\mathrm{b}} \quad=$ Luas bruto penampang baut

$\mathrm{m}=$ Jumlah bidang geser

$\rightarrow$ Kuat rencana: $\quad V_{d}=\emptyset_{\mathrm{f}} \mathrm{V}_{\mathrm{n}}$

Kuat tumpu nominal baut dengan plat

$\mathrm{R}_{\mathrm{t}}=2,4 \mathrm{~d}_{\mathrm{b}} \mathrm{t}_{\mathrm{p}} \mathrm{f}_{\mathrm{u}}$

Dimana:

$\mathrm{d}_{\mathrm{b}}=$ Diameter lubang $(\mathrm{mm})$

$\mathrm{t}_{\mathrm{p}}=$ Tebal plat yang disambung $(\mathrm{mm})$

$\mathrm{f}_{\mathrm{u}}=$ Tegangan tarik putus terkecil antara baut dan plat

$\rightarrow$ Kuat rencana: $\quad V t=\emptyset_{\mathrm{f}} \mathrm{R}_{\mathrm{n}}$

Kuat baut Rencana:

$\emptyset \mathrm{R}_{\mathrm{n}}$ diambil dari yang terkecil antara persamaan (18a) dan (19a)

Kuat tarik nominal baut

$$
\mathrm{T}_{\mathrm{n}}=0,75 \mathrm{f}_{\mathrm{u}}^{\mathrm{b}} \mathrm{A}_{\mathrm{b}}
$$

Dimana:

$\mathrm{f}_{\mathrm{u}}^{\mathrm{b}} \quad=$ Tegangan tarik putus baut

$\mathrm{A}_{\mathrm{b}} \quad=$ Luas bruto penampang baut

$$
\rightarrow \text { Kuat rencana: } \quad T_{d}=\emptyset_{f} T_{n}
$$

\section{METODOLOGI}

Metodologi pada penelitian ini terdiri dari beberapa tahap meliputi, pengumpulan data, analisa perhitungan dan kesimpulan. Sebelum tahap anlisa perhitungan dimulai terlebih dahulu ditentukan parameter-parameter perencanaan seperti diperlihatkan pada Tabel 3.1 dan Gambar 3.2. Variasi bentang kuda-kuda rangka baja hanya dilakukan pada jenis rangka batang yaitu rangka model paralel dan rangka model segitiga. Dimensi rangka batang yang ditetapkan beserta penomoran batangnya diperlihatkan pada Gambar 3.1.

Tabel 3. Data Perencanaan Kuda-kuda Baja

\begin{tabular}{|cll|}
\hline No & \multicolumn{1}{c|}{ Data } & \multicolumn{1}{c|}{ Keterangan } \\
\hline 1 & Jenis bangunan & Tertutup (Gudang) \\
2 & Jenis struktur & $\begin{array}{l}\text { Rangka batang statis tak } \\
\text { tentu }\end{array}$ \\
& & $66 \mathrm{~m}$ \\
3 & Panjang bangunan & $20 \mathrm{~m}$ dan $30 \mathrm{~m}$ \\
4 & Lebar bangunan & $6 \mathrm{~m}$ \\
5 & Jarak portal/kuda-kuda \\
6 & Kemiringan kuda-kuda & \\
7 & Peraturan pembebanan & $20^{\circ}$ \\
& Peraturan perencanaan & \\
8 & Mutu baja & PPIUG 1983 \\
& Profil gording & SNI 03-1729-2002 \\
9 & Profil batang & BJ-37 (2400 kg/m) \\
10 & & Baja lip channels \\
11 & Penutup atap & Baja double siku sama \\
12 & Tebal pelat simpul dan & kaki \\
& kopel & Seng gelombang \\
13 & Sambungan & 10 mm \\
14 & & Baut \\
& & \\
15 & &
\end{tabular}

Perhitungan dimulai terhadap panjang batang, lalu dilanjutkan dengan perhitungan beban serta mendimensi gording. Beban yang bekerja pada rangka batang didistribusikan pada titik-titik buhul. Beban-beban tersebut kemudian dimasukan ke dalam Anlisa Struktur dengan menggunakan SAP2000 v.14.0.0. Selanjutnya dapat dicari ukuran jenis gaya yang diterima tiap-tiap batang yang terbesar pada profil batang, terdiri dari batang tarik dan batang tekan sesuai konfigurasi masing-masing penampang.

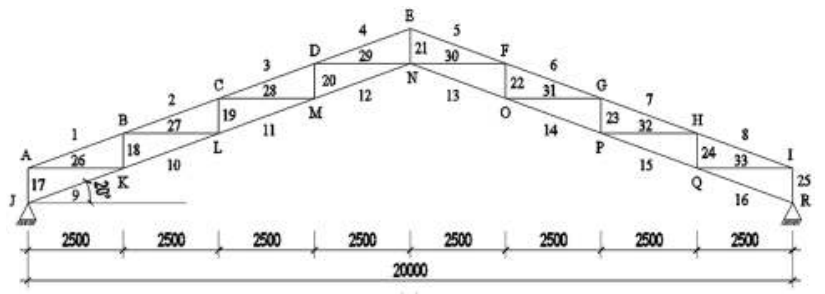

(a)

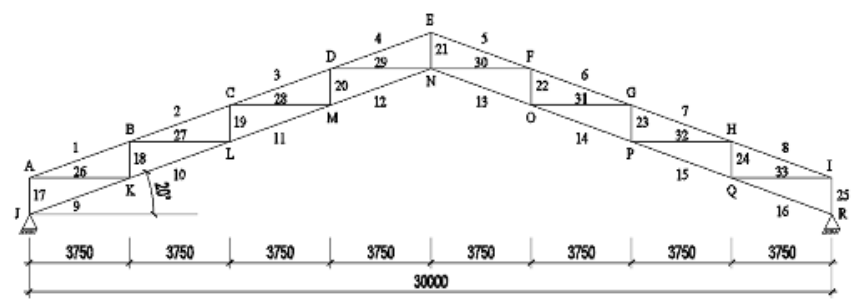

(b)

Gambar 3. Dimensi Kuda-kuda rangka baja model paralel 20 m (a) dan model paralel $30 \mathrm{~m} \mathrm{(b)}$ 


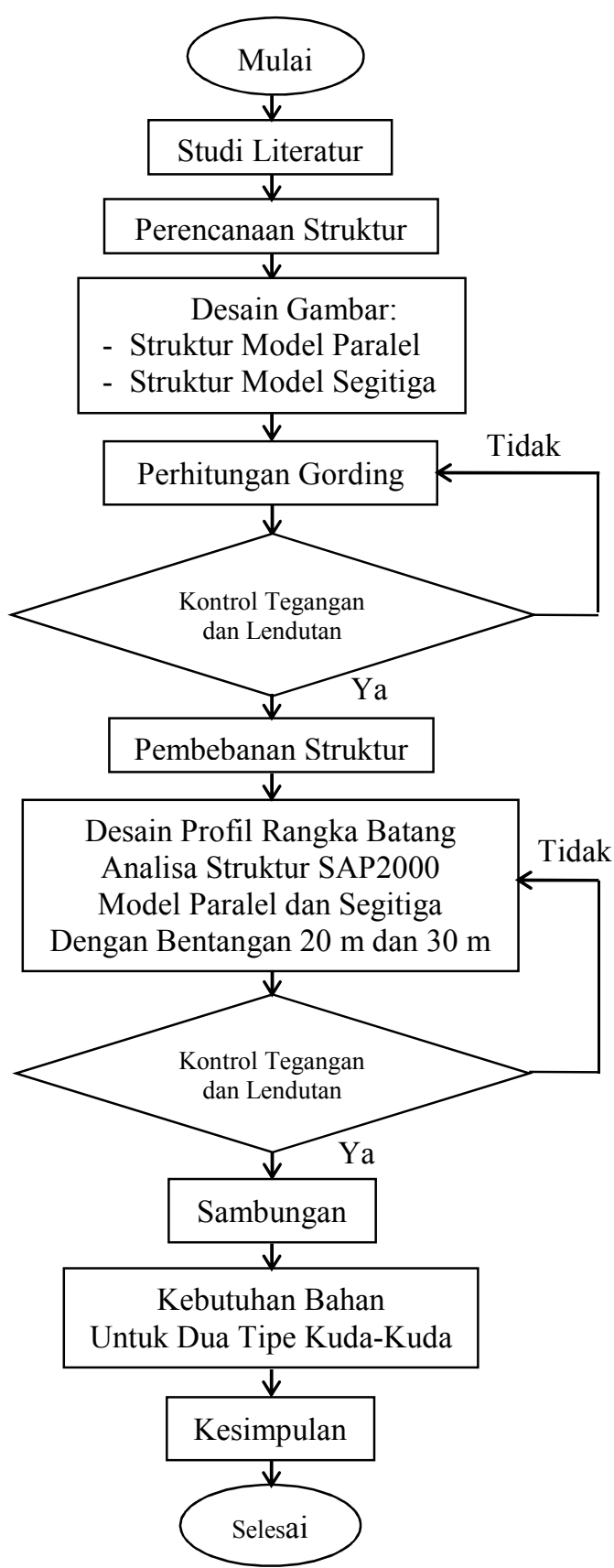

Gambar 4. Diagram alir penelitian

\section{Perencanaan Batang Tarik}

Elemen rangka batang terdiri dari batang tarik dan batang tekan. Perencanaan batang tarik lebih sederhana dari pada perencanaan batang tekan. Dasar perencanaan batang tarik memakai Persamaan (4). Ukuran profil batang tarik dipilih berdasarkan luas penampang netto yang didapat dari persamaan tersebut. Dalam penelitian/perencanaan ini sebagai alat sambung dipakai baut,

\section{Perencanaan Batang Tekan}

Prinsip dasar perencanaan batang tekan ditunjukkan dengan Persamaan (8). yang menunjukkan perlunya/adanya stabilitas batang terhadap bahaya tekuk. Faktor tekuk dapat dicari pada daftar tekuk dalam SNI 031729-2002 berdasarkan nilai kelangsingan maksimum antara Persamaan (11) sampai Persamaan (15). Setelah perencanaan kuda-kuda selesai hingga pemeriksaan lendutannya, maka berat total kedua jenis kuda-kuda dapat dihitung, yaitu dengan menjumlahkan berat masingmasing batang. Akhirnya dapat diketahui jenis mana yang lebih ringan yang secara umum merupakan yang paling efesien (ekonomis).

\section{Hasil Penelitian dan Pembahasan}

Dari hasil perhitungan beban serta pelimpahannya pada rangka atap diperlihatkan pada Gambar 4.1 sampai Gambar 4.6. Untuk beban angin arah tekan diabaikan karena koefesien pada angin tekan hasilnya $0 \mathrm{~kg}$ dan besarnya beban pada rangka model paralel sama dengan rangka model segitiga, namun pada gambar hanya ditunjukkan untuk jenis rangka model paralel bentang 20 $\mathrm{m}$ dan $30 \mathrm{~m}$, diantaranya:

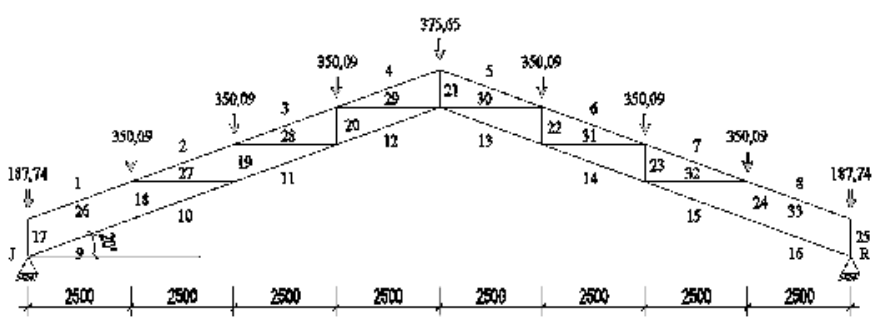

Gambar 5. Beban mati (kg) pada rangka atap bentang $20 \mathrm{~m}$
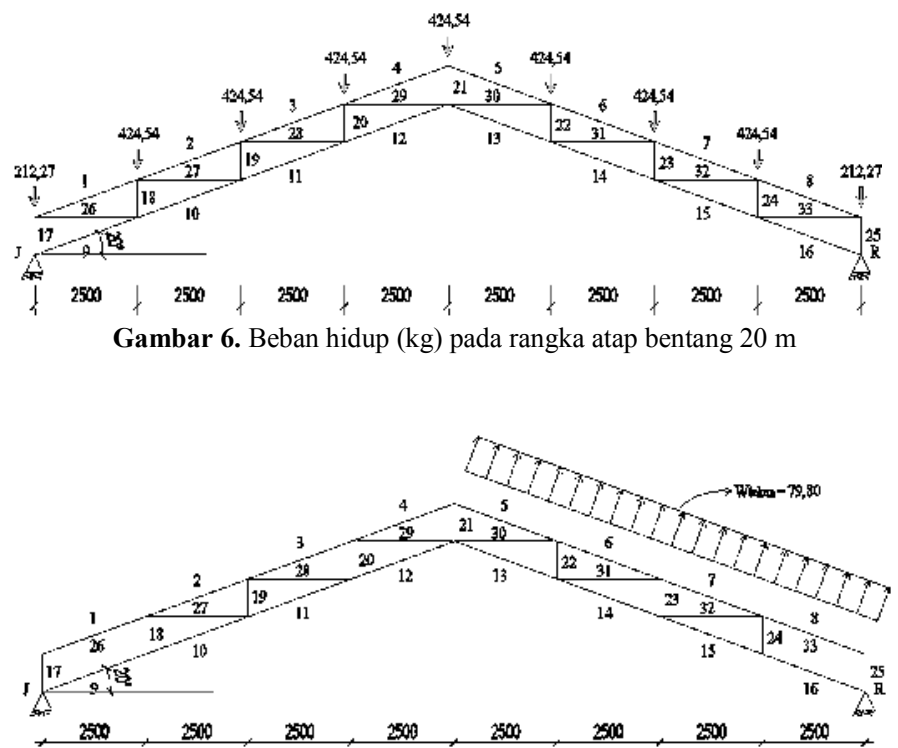

Gambar 7. Beban angin $(\mathrm{kg})$ pada rangka atap bentang $20 \mathrm{~m}$ 


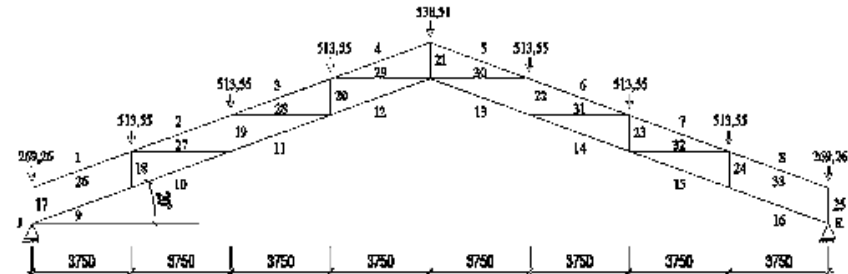

Gambar 8. Beban mati (kg) pada rangka atap bentang $30 \mathrm{~m}$

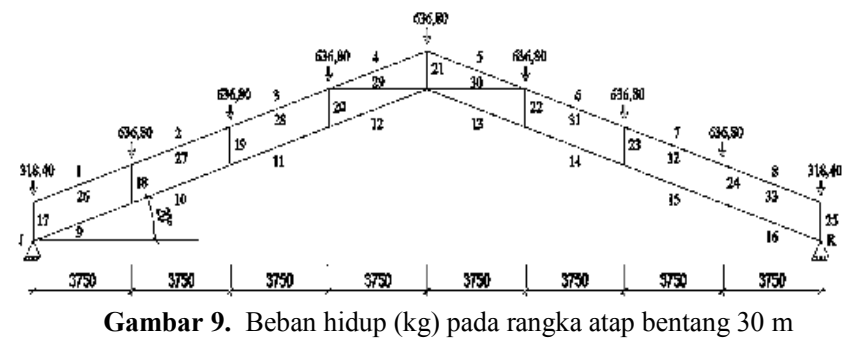

Gambar 9. Beban hidup (kg) pada rangka atap bentang $30 \mathrm{~m}$

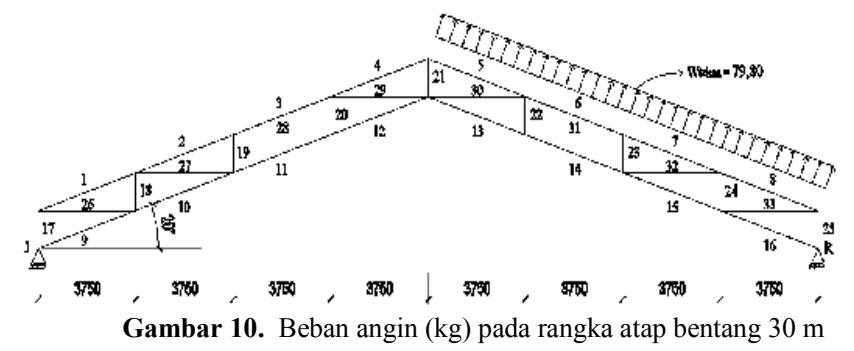

\section{Perencanaan Profil Rangka Batang}

Perencanaan kedua jenis model rangka batang dengan bentang $20 \mathrm{~m}$ dan $30 \mathrm{~m}$ dilakukan dengan bantuan program Analisa Struktur SAP2000 serta berdasarkan persamaan-persamaan di atas dengan merujuk data dalam Tabel 3 Dalam perencanaan ini gaya dalam terbesar pada kombinasi 2, serta dimensi profil minimum dibatasi, sambungan dan pelat kopel ditinjau. Hasil perhitungan selengkapnya ditampilkan dalam Tabel 4 sampai Tabel 7.

Tabel 4. Hasil Perhitungan Rangka Model Paralel 20 m

\begin{tabular}{|c|c|c|c|c|c|c|}
\hline \multirow{2}{*}{$\begin{array}{c}\text { No. } \\
\text { Batang }\end{array}$} & \multicolumn{2}{|c|}{ Gaya (kg) } & \multirow{2}{*}{ Profil } & \multirow{2}{*}{$\begin{array}{c}\text { Berat } \\
\text { doube } \\
\text { I } \\
\text { Profil } \\
(\mathrm{kg} / \mathrm{m} \\
\text { ) }\end{array}$} & \multirow{2}{*}{$\begin{array}{c}\text { Panjan } \\
\text { g (m) }\end{array}$} & \multirow{2}{*}{$\begin{array}{l}\text { Berat } \\
\text { Batan } \\
\text { g (kg) }\end{array}$} \\
\hline & Tekan & Tarik & & & & \\
\hline $1=8$ & & & 2L60.60.6 & 10,84 & 2,660 & 57,67 \\
\hline $2=7$ & 6545 & & 2L60.60.6 & 10,84 & 2,660 & 57,67 \\
\hline $3=6$ &, 43 & & 2L60.60.6 & 10,84 & 2,660 & 57,67 \\
\hline $4=5$ & & & 2L60.60.6 & 10,84 & 2,660 & 57,67 \\
\hline $9=16$ & & $\mathbf{9 7 7 , 9 3}$ & 2L60.60.6 & 10,84 & 2,660 & 57,67 \\
\hline $10=15$ & & & 2L60.60.6 & 10,84 & 2,660 & 57,67 \\
\hline $11=14$ & & & 2L60.60.6 & 10,84 & 2,660 & 57,67 \\
\hline $12=13$ & & & 2L60.60.6 & 10,84 & 2,660 & 57,67 \\
\hline $17=25$ & 7319 & & 2L30.30.3 & 2,72 & 0,910 & 4,95 \\
\hline $18=24$ & 31 & & 2L30.30.3 & 2,72 & 0,910 & 4,95 \\
\hline $19=23$ & & & 2L30.30.3 & 2,72 & 0,910 & 4,95 \\
\hline $20=22$ & & & 2L30.30.3 & 2,72 & 0,910 & 4,95 \\
\hline 21 & $\begin{array}{c}2319 \\
5\end{array}$ & & 2L30.30.3 & 2,72 & 0,910 & 2,47 \\
\hline $26=33$ & & 736,44 & 2L50.50.7 & 10,30 & 2,500 & 51,50 \\
\hline $27=32$ & & & 2L50.50.7 & 10,30 & 2,500 & 51,50 \\
\hline $28=31$ & 517 & 4723,0 & 2L50.50.7 & 10,30 & 2,500 & 51,50 \\
\hline $29=30$ & 9,74 & 2 & 2L50.50.7 & 10,30 & 2,500 & 51,50 \\
\hline & Berat & l Ran & rofil 1 & -kuda & & 689,63 \\
\hline
\end{tabular}

Tabel 5. Hasil Perhitungan Rangka Model Segitiga 20 m

\begin{tabular}{|c|c|c|c|c|c|c|}
\hline \multirow{2}{*}{$\begin{array}{c}\text { No. } \\
\text { Batang }\end{array}$} & \multicolumn{2}{|c|}{ Gaya (kg) } & \multirow{2}{*}{ Profil } & \multirow{2}{*}{$\begin{array}{c}\text { Berat } \\
\text { doubel } \\
\text { Profil } \\
(\mathrm{kg} / \mathrm{m})\end{array}$} & \multirow{2}{*}{$\begin{array}{c}\text { Panjang } \\
\text { (m) }\end{array}$} & \multirow{2}{*}{$\begin{array}{c}\text { Berat } \\
\text { Batang } \\
(\mathbf{k g})\end{array}$} \\
\hline & Tekan & Tarik & & & & \\
\hline $1=8$ & 12603 , & & 2L70.70.7 & 14,76 & 2,660 & 78,53 \\
\hline $2=7$ & 35 & & 2L70.70.7 & 14,76 & 2,660 & 78,53 \\
\hline $3=6$ & & & 2L 70.70 .7 & 14,76 & 2,660 & 78,53 \\
\hline $4=5$ & & & 2L 70.70 .7 & 14,76 & 2,660 & 78,53 \\
\hline $9=16$ & & 1238,44 & 2L 45.45 .5 & & 2,500 & 33,80 \\
\hline $10=15$ & & & 2L 45.45 .5 & 6,76 & 2,500 & 33,80 \\
\hline $11=14$ & & & 2L 45.45 .5 & 6,76 & 2,500 & 33,80 \\
\hline $12=13$ & 2073,9 & & 2L 45.45 .5 & 6,76 & 2,500 & 33,80 \\
\hline $17=23$ & 4 & & 2L 45.45 .5 & 6,76 & 0,910 & 12,31 \\
\hline $18=22$ & & & 2L 45.45 .5 & 6,76 & 1,820 & 24,61 \\
\hline $19=21$ & & & 2L 45.45 .5 & 6,76 & 2,730 & 36,91 \\
\hline 20 & & 3798,48 & 2L 45.45 .5 & 6,76 & 3,640 & 24,61 \\
\hline $24=29$ & & & & 6,76 & & \\
\hline $25=28$ & 2523,3 & & 2L65.65.7 & 13,66 & 2,660 & 72,67 \\
\hline \multirow[t]{2}{*}{$26=27$} & 8 & & 2L65.65.7 & 13,66 & 3,092 & 84,50 \\
\hline & & & 2L65.65.7 & 13,66 & 3,702 & 101,14 \\
\hline \multicolumn{6}{|c|}{ Berat Total Rangka Profil 1 Kuda-kuda } & 806,07 \\
\hline
\end{tabular}

Tabel 6. Hasil Perhitungan Rangka Model Paralel 30 m

\begin{tabular}{|c|c|c|c|c|c|c|}
\hline \multirow{2}{*}{$\begin{array}{c}\text { No. } \\
\text { Batang }\end{array}$} & \multicolumn{2}{|c|}{ Gaya (kg) } & \multirow{2}{*}{ Profil } & \multirow{2}{*}{$\begin{array}{c}\text { Berat } \\
\text { doubel } \\
\text { Profil } \\
(\mathrm{kg} / \mathrm{m})\end{array}$} & \multirow{2}{*}{$\begin{array}{c}\text { Panjang } \\
\text { (m) }\end{array}$} & \multirow{2}{*}{$\begin{array}{c}\text { Berat } \\
\text { Batang } \\
(\mathrm{kg})\end{array}$} \\
\hline & Tekan & Tarik & & & & \\
\hline $1=8$ & & \multirow{11}{*}{1514,02} & 2L80.80.10 & 23,80 & 3,991 & 189,97 \\
\hline $2=7$ & & & 2L 80.80 .10 & 23,80 & 3,991 & 189,97 \\
\hline $3=6$ & 10604 , & & 2L80.80.10 & 23,80 & 3,991 & 189,97 \\
\hline $4=5$ & 97 & & 2L80.80.10 & 23,80 & 3,991 & 189,97 \\
\hline $9=16$ & & & 2L80.80.10 & 23,80 & 3,991 & 189,97 \\
\hline $10=15$ & & & 2L80.80.10 & 23,80 & 3,991 & 189,97 \\
\hline $11=14$ & & & 2L80.80.10 & 23,80 & 3,991 & 189,97 \\
\hline $12=13$ & 11769,8 & & 2L80.80.10 & 23,80 & 3,991 & 189,97 \\
\hline $17=25$ & $\mathbf{0}$ & & 2L35.35.4 & 4,20 & 1,365 & 11,47 \\
\hline $18=24$ & & & L35.35.4 & 4,20 & 1,365 & 11,47 \\
\hline $19=23$ & & & 2L 35.35 .4 & 4,20 & 1,365 & 11,47 \\
\hline $20=22$ & & \multirow[t]{2}{*}{1251,85} & 2L 35.35 .4 & 4,20 & 1,365 & 11,47 \\
\hline 21 & 3710,5 & & 2L 35.35 .4 & 4,20 & 1,365 & 5,73 \\
\hline $26=33$ & 8 & \multirow{4}{*}{7635,96} & & 15,88 & 3,750 & 119,10 \\
\hline $27=32$ & 8338, & & 2L75.75.7 & 15,88 & 3,750 & 119,10 \\
\hline $28=31$ & 25 & & 2L75.75.7 & 15,88 & 3,750 & 119,10 \\
\hline $29=30$ & & & & 15,88 & 3,750 & 119,10 \\
\hline \multicolumn{6}{|c|}{ Berat Total Rangka Profil 1 Kuda-kuda } & 2047,77 \\
\hline
\end{tabular}

Tabel 7. Hasil Perhitungan Rangka Model Segitiga $30 \mathrm{~m}$

\begin{tabular}{|c|c|c|c|c|c|c|}
\hline \multirow[b]{2}{*}{$\begin{array}{c}\text { No. } \\
\text { Batang }\end{array}$} & \multicolumn{2}{|c|}{ Gaya (kg) } & \multirow[b]{2}{*}{ Profil } & \multirow{2}{*}{$\begin{array}{c}\text { Berat } \\
\text { doubel } \\
\text { Profil } \\
(\mathrm{kg} / \mathrm{m})\end{array}$} & \multirow[b]{2}{*}{$\begin{array}{c}\text { Panjan } \\
\text { g (m) }\end{array}$} & \multirow{2}{*}{$\begin{array}{c}\text { Berat } \\
\text { Batang } \\
\text { (kg) }\end{array}$} \\
\hline & Tekan & Tarik & & & & \\
\hline $1=8$ & 20991,64 & & 2L90.90.13 & 34,20 & 3,991 & 272,98 \\
\hline $2=7$ & & & 2L90.90.13 & 34,20 & 3,991 & 272,98 \\
\hline $3=6$ & & & 2L90.90.13 & 34,20 & 3,991 & 272,98 \\
\hline $4=5$ & & & 2L90.90.13 & 34,20 & 3,991 & 272,98 \\
\hline $9=16$ & & 2030,12 & 2L65.65.7 & 13,66 & 3,750 & 102,45 \\
\hline $10=15$ & & & 2L65.65.7 & 13,66 & 3,750 & 102,45 \\
\hline $11=14$ & & & 2L65.65.7 & 13,66 & 3,750 & 102,45 \\
\hline $12=13$ & 3414,24 & & 2L65.65.7 & 13,66 & 3,750 & 102,45 \\
\hline $17=23$ & & & 2L60.60.6 & 10,84 & 1,365 & 29,60 \\
\hline $18=22$ & & & 2L60.60.6 & 10,84 & 2,730 & 59,19 \\
\hline $19=21$ & & & 2L60.60.6 & 10,84 & 4,095 & 88,78 \\
\hline 20 & & 6494,43 & 2L60.60.6 & 10,84 & 5,460 & 59,19 \\
\hline $24=29$ & & & 2L100.100.10 & 30,20 & 3,991 & 241,06 \\
\hline $25=28$ & & & 2L100.100.10 & 30,20 & 4,638 & 280,14 \\
\hline $26=27$ & 4252,65 & & $2 \mathrm{~L} 100.100 .10$ & 30,20 & 5,553 & 335,40 \\
\hline \multicolumn{6}{|c|}{ Berat Total Rangka Profil 1 Kuda-kuda } & 2594,98 \\
\hline
\end{tabular}




\section{Rekapitulasi Hasil Perhitungan}

Tabel 8. Hasil Perhitungan Berat Kontruksi Model Paralel

\begin{tabular}{|clcc|}
\hline \multirow{2}{*}{ No } & \multirow{2}{*}{ Jenis Struktur (kg) } & \multicolumn{2}{c|}{$\begin{array}{c}\text { Model Kuda-kuda } \\
\text { Paralel }\end{array}$} \\
\cline { 3 - 4 } & & $\mathbf{2 0 ~ \mathbf { ~ }}$ & $\mathbf{3 0 ~ \mathbf { ~ }}$ \\
\hline 1 & Rangka Batang & 7585,90 & 22525,47 \\
2 & Gording & 9884,16 & 14277,12 \\
3 & Pengg. Gording & 51,51 & 77,26 \\
4 & Ikatan Angin & 150,12 & 187,00 \\
5 & Baut & 23,57 & 44,82 \\
6 & Berat Atap & 15833,12 & 23069,68 \\
\hline & Jumlah Total & $\mathbf{3 3 5 2 8 , 3 8}$ & $\mathbf{6 0 1 8 1 , 3 5}$ \\
\hline
\end{tabular}

Tabel 9 Hasil Perhitungan Berat Kontruksi Model Segitiga

\begin{tabular}{|clcc|}
\hline \multirow{2}{*}{ No } & Jenis Perhitungan $(\mathrm{kg})$ & \multicolumn{2}{c|}{ Sodel Kuda-kuda } \\
& & $20 \mathrm{~m}$ & $30 \mathrm{~m}$ \\
\hline 1 & Rangka Batang & 8866,79 & 28544,79 \\
2 & Gording & 9884,16 & 14277,12 \\
3 & Pengg. Gording & 51,51 & 77,26 \\
4 & Ikatan Angin & 150,12 & 187,00 \\
5 & Baut & 31,06 & 62,09 \\
6 & Berat Atap & 15833,12 & 23069,68 \\
\hline & Jumlah Total & $\mathbf{3 4 8 1 6 , 7 5}$ & $\mathbf{6 6 2 1 7 , 9 4}$ \\
\hline
\end{tabular}

Tabel 10. Hasil Perhitungan Pelat Simpul dan Pelat Kopel

\begin{tabular}{|c|c|c|c|c|c|}
\hline \multirow{2}{*}{$\begin{array}{l}\mathrm{N} \\
\mathrm{o}\end{array}$} & \multirow{2}{*}{$\begin{array}{c}\text { Jenis } \\
\text { Perhitungan } \\
(\mathrm{kg})\end{array}$} & \multicolumn{2}{|c|}{$\begin{array}{l}\text { Model Kuda-kuda } \\
\text { Paralel }\end{array}$} & \multicolumn{2}{|c|}{$\begin{array}{l}\text { Model Kuda-kuda } \\
\text { Segitiga }\end{array}$} \\
\hline & & $20 \mathrm{~m}$ & $30 \mathrm{~m}$ & $20 \mathrm{~m}$ & $30 \mathrm{~m}$ \\
\hline 1 & Pelat Simpul & 769,89 & 1141,97 & 625,37 & 890,45 \\
\hline 2 & $\begin{array}{l}\text { Pelat } \\
\text { Kopel }\end{array}$ & 918,59 & 2203,65 & $\begin{array}{c}1113,4 \\
3\end{array}$ & 2371,49 \\
\hline \multicolumn{2}{|c|}{ Jumlah Total } & 1688,48 & 3345,62 & $\begin{array}{c}1738,8 \\
0\end{array}$ & 3261,94 \\
\hline
\end{tabular}

Tabel 11. Perhitungan Berat Total

\begin{tabular}{|c|c|c|c|c|c|}
\hline \multirow[t]{2}{*}{ No } & \multirow{2}{*}{$\begin{array}{c}\text { Jenis } \\
\text { Perhitunga } \\
\text { n (kg) }\end{array}$} & \multicolumn{2}{|c|}{$\begin{array}{c}\text { Model Kuda-kuda } \\
\text { Paralel }\end{array}$} & \multicolumn{2}{|c|}{$\begin{array}{l}\text { Model Kuda-kuda } \\
\text { Segitiga }\end{array}$} \\
\hline & & $20 \mathrm{~m}$ & $30 \mathrm{~m}$ & $20 \mathrm{~m}$ & $30 \mathrm{~m}$ \\
\hline 1 & $\begin{array}{l}\text { Pelat } \\
\text { Simpul }\end{array}$ & 769,89 & 1141,97 & 625,37 & 890,45 \\
\hline 2 & $\begin{array}{l}\text { Pelat } \\
\text { Kopel }\end{array}$ & 918,59 & 2203,65 & 1113,43 & 2371,49 \\
\hline 3 & $\begin{array}{c}\text { Berat } \\
\text { Kontruksi }\end{array}$ & 33528,38 & 60181,35 & 34816,75 & 66217,94 \\
\hline \multicolumn{2}{|c|}{ Jumlah Total } & 35216,86 & 63526,97 & 36555,55 & 69479,88 \\
\hline
\end{tabular}

Tabel 12. Hasil Perhitungan Penurunan/Selisih Berat Total

\begin{tabular}{|c|c|c|c|c|}
\hline \multirow{3}{*}{ Jenis Perhitungan } & \multicolumn{2}{|c|}{ Model Kuda-kuda } & \multicolumn{2}{|c|}{ Model Kuda-kuda } \\
\hline & Paralel & Segitiga & Paralel & Segitiga \\
\hline & \multicolumn{2}{|c|}{$20 \mathrm{~m}$} & \multicolumn{2}{|c|}{$30 \mathrm{~m}$} \\
\hline Berat Total (kg) & 35216,86 & 36555,55 & 63526,97 & 69479,88 \\
\hline Selisih & \multicolumn{2}{|c|}{1338,69} & \multicolumn{2}{|c|}{5952,92} \\
\hline Persentase $(\%)$ & \multicolumn{2}{|c|}{3,66} & \multicolumn{2}{|c|}{8,57} \\
\hline
\end{tabular}

Berdasarkan hasil perhitungan rangka batang kudakuda dari beberapa tipe yang mengunakan profil double siku sama kaki, pada Tabel 12 menunjukkan bahwa kebutuhan berat total kuda-kuda pada bentang $20 \mathrm{~m}$ dengan jarak portal $6 \mathrm{~m}$, Tipe I model parallel lebih efesien dari pada Tipe II model segitiga dengan selisih berat 1338,69 $\mathrm{kg}$ atau prosentase sebesar 3,66\%, Sedangkan pada bentang $30 \mathrm{~m}$ Tipe III model paralel lebih efesien dari pada Tipe IV model segitiga dengan selisih berat 5952,92 kg atau prosentase sebesar $8,57 \%$.

Lendutan dari pemodelan dan analisa SAP2000 v.14.0.0 kombinasi maksimum beban mati dan beban hidup (DSTL2) untuk dua tipe kuda-kuda baja bentang $20 \mathrm{~m}$ dan $30 \mathrm{~m}$ diperoleh lendutan yang terjadi, yaitu:

- Bentang $20 \mathrm{~m} \rightarrow\left(20000 / 240=\delta_{\text {izin }}=83,33\right.$ $\mathrm{mm})$

Tipe I paralel $=\left(6,11 \mathrm{~mm}<\delta_{\text {izin }}=83,33 \mathrm{~mm}\right)$

Tipe II segitiga $=\left(8,94 \mathrm{~mm}<\delta_{\text {izin }}=83,33 \mathrm{~mm}\right)$

- Bentang $30 \mathrm{~m} \rightarrow\left(30000 / 240=\delta_{\text {izin }}=125\right.$ $\mathrm{mm})$

Tipe III paralel $=\quad\left(7,72 \mathrm{~mm}<\delta_{\text {izin }}=\right.$ $125 \mathrm{~mm}$ )

Tipe IV segitiga $=\quad\left(10,15 \mathrm{~mm}<\delta_{\text {izin }}=\right.$ $125 \mathrm{~mm})$

\section{KESIMPULAN DAN SARAN}

\section{Kesimpulan}

Berdasarkan hasil perhitungan pada grafik berat total terhadap variasi bentangan, maka dalam perencanaan ini bahwa rangka kuda-kuda model paralel lebih efisen dari model segitga karena adanya perbedaan dimensi profil dan panjang batang pada kedua jenis model kuda-kuda.

\section{Saran}

Mengingat dari hasil perhitungan semakin besar bentang rangka kuda-kuda parallel semakin ekonomis, maka disarankan untuk melakukan penelitian yang sejenis dengan bentangan yang lebih besar untuk mendapatkan hasil yang akurat. 


\section{DAFTAR PUSTAKA}

Azhari dkk, 2015." Perbandingan Berat Kuda-kuda Rangka Baja Jenis Rangka Howe Dengan Rangka Pratt", Journal, ISBN: 978-979792-636-6, Pekanbaru: Universitas Riau.

Budiman, Arif, 2011. "Perbandingan Volume Kebutuhan Material Kudakuda Rangka Atap Baja Tipe Pratt, Howe, Compound Fan”, Journal, ISSN: 1907-4360, Jakarta: Universitas Negeri Jakarta.

Departemen Pekerjaan Umum, 2002. "Tata Cara Perencanaan Struktur Baja Untuk Bangunan Gedung “, SNI 03-1729-2002, Bandung: 2002.

Dewobroto, Wiryanto, 2013." Komputer Rekayasa Struktur Dengan SAP2000", Jakarta: Penerbit Lumina Press, 2013.

Direkot Penyelidikan Masalah Bangunan, Departemen Pekerjaan Umum, Dirjen Cipta Karya. 1983. "Peraturan Pembebanan Indonesia Untuk Gedung”, 1983, Bandung: 1983.

Gunawan, Rudy, 1988. "Tabel Profil Kontruksi Baja”, Yogyakarta: Penerbit Kanisius, 1988.

Istiqomah, Ade Tias, 2015. "Redesain Gedung Apartemen The Pinnacle Empat Lantai Jalan Pandanaran Semarang", Tugas Akhir,: Universitas Negeri Semarang.

Jibja, Billah Wirat, 2016. Perencanaan Ulang Struktur Baja Atap Tinggi Warehouse Menggunakan Sistem Rangka Batang Dengan Metode LRFD, Tugas Akhir, Jakarta: Universitas Mercu Buana.

Salmon, Charles G \& Johnson, Jhon E, 1992. "Struktur Baja I : Desain dan Perilaku", Jakarta: Penerbit Gramedia Pustaka Utama, 1992.

Setiawan, Agus, 2015. “Analisa Struktur”, Jakarta: Penerbit Erlangga, 2015. 